Ya.S. Bederak

\title{
ON SUBSTANTIATION OF SELECTION OF ECONOMIC AND MATHEMATICAL METHODS FOR THE ASSESSMENT OF ENERGY EFFICIENCY OF PRODUCTION FACILITIES
}

Research purpose is generalization and further development of economic- mathematical methods for ensuring energy-efficient operation mode of production facilities. The above methods can be used for selection of the most energy-efficient production lines, mechanisms; pumping, compression, ventilation installations or other electric receivers among several similar ones by using equal and unequal weight criteria. An example of comparing the efficiency of the production facilities of the chemical industry is showed by a priori ranking and morphological (geometric) methods. The method of control the correctness of the production facilities in the case when the electric load depends on two parameters in triangular coordinates in the presence of boundary restrictions is described. The identity of the current energy values calculated by Holt predicted value at a predetermined optimal smoothing constant determines the stability of the process. Expedience of application the autocorrelation coefficient for testing processes on the stability is proved. References 10 , tables 3 , figures 5.

Key words: power consumption, criteria of equal and unequal weights, the autocorrelation coefficient, energy efficiency.

Целью исследования является обоснование выбора наиболее целесообразных экономико-математических методов обеспечения энергоэффективного режима работы производственных объектов. Рассмотренные методы могут быть использованы для выбора наиболее энергоэффективных технологических линий, агрегатов, насосных, компрессорных, вентиляторных установок или других электроприемников с нескольких им подобных по равновесным и неравновесным критериям. Приведен пример сравнения эффективности работы производственных объектов химической промышленности методами априорного ранжирования и морфологическим (геометрическим). Описан способ контроля энергоэффективности работы производственных объектов в случае, когда электрическая нагрузка зависит от двух параметров при наличии предельных ограничений их, используя треугольные координаты. Сделан вывод о том, что тождество текущего значения энергопотребления с рассчитанным методом Хольта прогнозируемым значением при определенных заранее оптимальных постоянных сглаживания определяет стабильность работы технологического процесса. Доказана целесообразность применения коэффициента автокорреляции первого порядка выборок электропотребления для проверки технологических процессов на стабильность работы. Библ. 10, табл. 3 , рис. 5.

Ключевые слова: электропотребление, равновесные и неравновесные критерии, энергоэффективность, коэффициент автокорреляции.

Introduction. In industry it is often necessary to compare the energy efficiency of similar structure and functionality of two or more manufacturing facilities, such as production lines, machinery, pump, compressor, fan or other installations on several criteria (parameters) to select the best working unit. To do this, use the criteria as equal and unequal weight. Similarly, in practice we must solve the problem of determining the point in time during the change of day, decade, month, etc., which worked effectively manufacturing facility (or vice versa). It is necessary to provide real-time energy production facilities. These tasks proposed to deal with the known economic-mathematical methods and parameters.

The goal of the paper is substantiation of the most appropriate choice of economic and mathematical methods for energy-efficient mode of production facilities.

Analysis of recent investigations and publications. Statistical analysis in electricity supply systems (ESS) industry introduced by M.A. Denisenko in [1]. This approach is useful for other energy resources [2].

Methods of making the criteria equal and unequal scales considered in [3]. In this paper the technical working optimally choose an item using the procedure of constructing the utility function. To ensure efficient energy use and control operating mode processes appropriate to apply the control cards by Shewhart [4].

Material and research results. Investigations have shown that to ensure energy-efficient mode of production facilities necessary to carry out the following activities:

1. Monitoring the efficiency of technological process in the case when the electric load depends on two parameters.

Among all methods of visualization and control of process in the case when the electric load depends on two parameters, the easiest method is to use triangular coordinates [5]. Fig. 1 shows an example of building a triangular coordinate system for piston air compressor, which load (built on the axis $p$ ) depends directly proportional to the pressure (axis $m$ ) in the system and the temperature in the compressor (axis $n$ ). At the intersection of three straight arbitrary built equilateral triangle $\mathrm{ABC}$. He called triangular base coordinate system. Axis, and therefore the coordinates of points are indicated by the letters $m, n$ and $p$.

Using triangular coordinates, it is convenient to control the process, such as mode of operation piston air compressor (Fig. 2). Its power consumption depends on the pressure in the compressed air and the temperature of the compressed air in the system. 


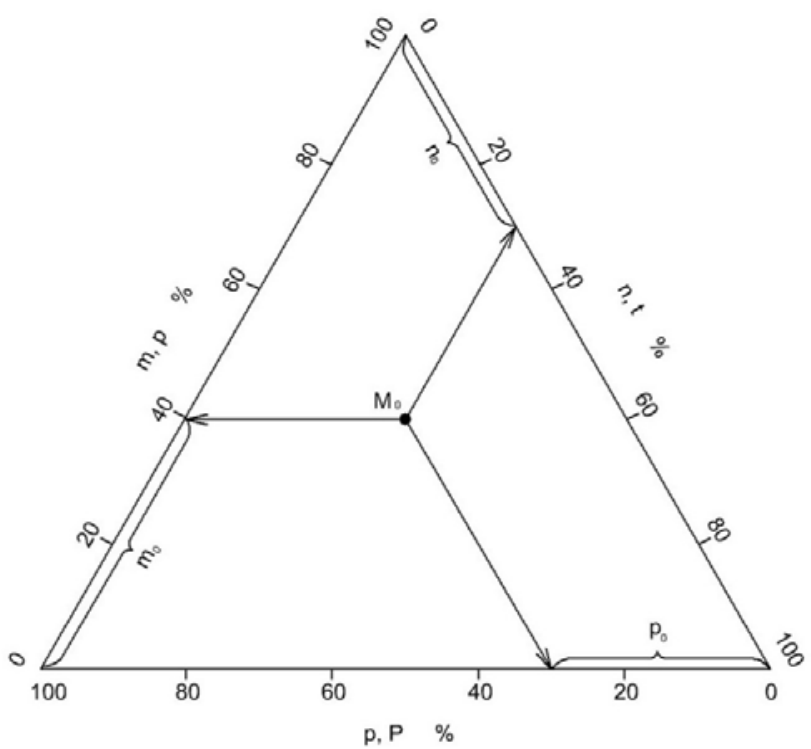

Fig. 1. Example of triangular frames for piston air compressor load which depends directly proportional to system pressure and air temperature in the compressor

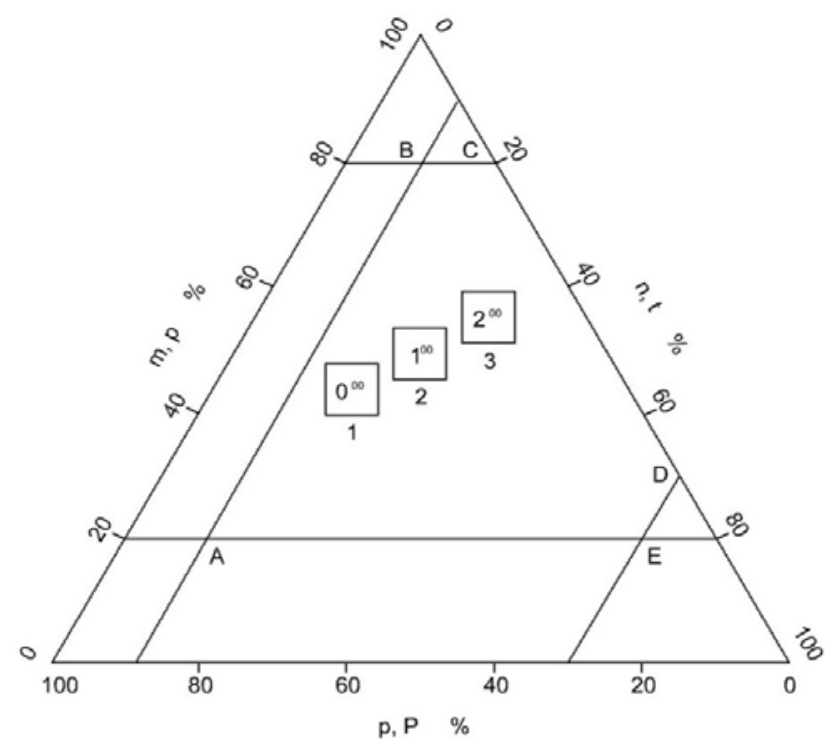

Fig. 2. Example of conducting the technological process by diagram $n$ triangular coordinates

On the axis $m$ delayed pressure in the compressed air in percentage, on the axis $n$ - the temperature of the compressed air system in percent, on the axis $p$ - capacity compressor at different time points percentage. When operating the compressor, there are several restrictions: maximum interval pressure on a percentage of 20-80\%, temperature $0-70 \%, 0-90 \%$ of capacity. Diagram of the process (Fig. 2) shows that the process should be conducted within the figure ABCDEA. The closer to the beginning of the axis is $p$ (power percentage), the compressor works more effectively [5].

2. Comparison of energy production facilities whose consumption depends on many different factors of equal weight.

The power consumption of production facilities can be affected by many different factors equal weight. To compare the energy efficiency of objects by partial (only one characterizing feature of object) criteria of equal weight may be used either additive or multiplicative generalized criteria [3]. Under criteria imply controlled output parameter characterizing the degree of achievement. Partial criteria $F_{i}(X)$ in one way or another should be combined in a general criterion $f(X)=\Phi\left[F_{1}(X)\right.$, $\left.F_{2}(X), \ldots, F_{m}(X)\right]$ which after that is optimized.

When all criteria are of equal value, the generalized additive criterion is written in the form of partial sums criteria in when they have the same weight. Multiplicative criterion is formed by simple multiplication of partial criteria in when they have the same weight. For when one object is better than generalized additive criterion and the other - for the multiplicative need to use to select the optimal geometric mathematical model (morphological) approach [6].

The morphological approach can be used not only for the comparison of the object at different times, but when using two identical units, production lines and so on. To use morphological approach requires the construction of radiation diagram. This chart is constructed as follows: from the center of the circle made by a number of factors straight lines (radii) that resemble rays diverge during radioactive decay. These tags are applied radii graduation in the fate of $100 \%$ and lay them in the data value percentage. The points, which are marked pending value, combine segments. The values that are the rays that correspond to each factor, compared with the reference value (standard energy) or values for the previous billing period. Each of technological facilities necessary to determine the specific rate of electricity consumption per unit of production or calculate standard consumption by the algorithm specified in [7].

For example, ammonia plant based radiation diagram which compares energy plant for two days in a row for the equilibrium quality criteria. These criteria include energy consumption, heat consumption, the consumption of recycled water, natural gas consumption, consumption of demineralized water, ammonia output. Table 1 shows the ratio of energy consumption per unit of output normalized to a value (standard or specific energy consumption norms).

Table 1

The value of the ratio of energy consumption per unit of output normalized to a value two days in a row

\begin{tabular}{|l|c|c|}
\hline \multicolumn{1}{|c|}{ Parameter } & $\begin{array}{c}\text { The value for the } \\
\text { first day and marking } \\
\text { points on the } \\
\text { radiation diagram, \% }\end{array}$ & $\begin{array}{c}\text { The value for the } \\
\text { second day and } \\
\text { marking points on the } \\
\text { radiation diagram, \% }\end{array}$ \\
\hline $\begin{array}{l}\text { Electrical energy } \\
\text { consumption }\end{array}$ & $100\left(\mathrm{~A}_{1}\right)$ & $87\left(\mathrm{~A}_{2}\right)$ \\
\hline $\begin{array}{l}\text { Heat energy } \\
\text { consumption }\end{array}$ & $110\left(\mathrm{~B}_{1}\right)$ & $90\left(\mathrm{~B}_{2}\right)$ \\
\hline $\begin{array}{l}\text { Recycled water } \\
\text { consumption }\end{array}$ & $105\left(\mathrm{C}_{1}\right)$ & $91\left(\mathrm{C}_{2}\right)$ \\
\hline $\begin{array}{l}\text { Demineralized } \\
\text { water } \\
\text { consumption }\end{array}$ & $108\left(\mathrm{D}_{1}\right)$ & $94\left(\mathrm{D}_{2}\right)$ \\
\hline $\begin{array}{l}\text { Natural gas } \\
\text { consumption }\end{array}$ & $115\left(\mathrm{E}_{1}\right)$ & $95\left(\mathrm{E}_{2}\right)$ \\
\hline Ammonia output & $103\left(\mathrm{~F}_{1}\right)$ & $96\left(\mathrm{~F}_{2}\right)$ \\
\hline
\end{tabular}

Example of the determination the best working object is shown in Fig. 3. 


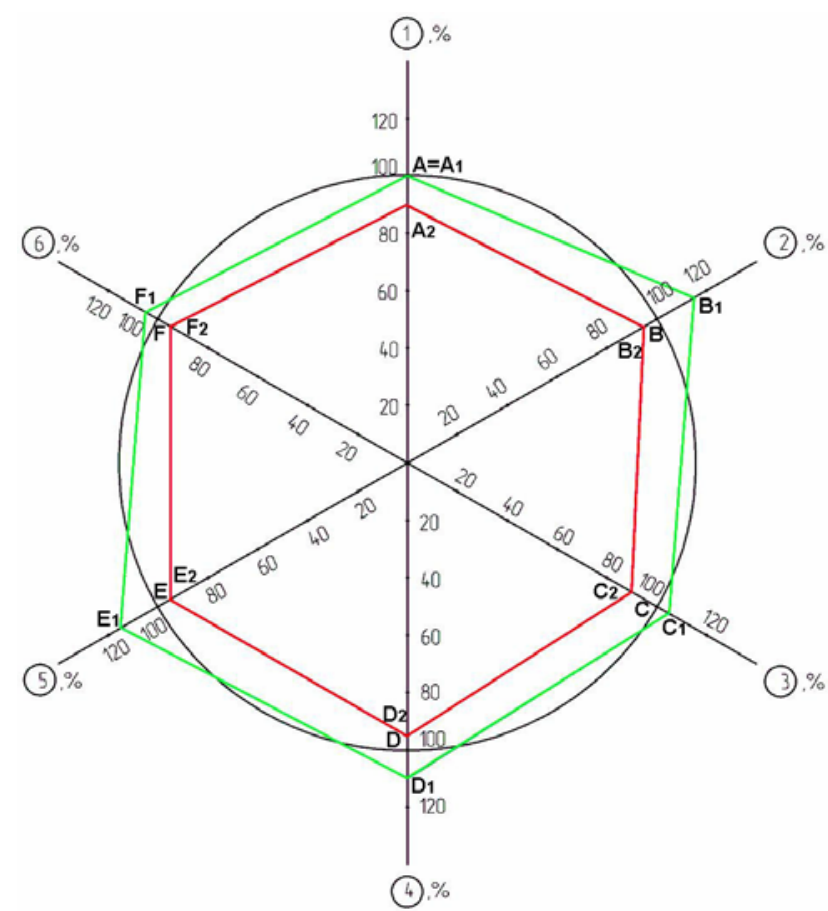

Fig. 3. Radiation diagram comparing the energy efficiency of ammonia production plant with two days in a row for the equilibrium quality criteria

Designations in Fig. 3: beam 1 - percentage of the «standard of consumption» in electricity (it are points $A_{1}$ and $\left.A_{2}\right), 2$ - by heat energy $\left(B_{1}\right.$ and $\left.B_{2}\right), 3$ - by circulating water $\left(C_{1}\right.$ and $\left.C_{2}\right), 4$ - by demineralized water $\left(D_{1}\right.$ and $\left.\mathrm{D}_{2}\right), 5$ - by consumption of natural gas $\left(\mathrm{E}_{1}\right.$ and $\left.\mathrm{E}_{2}\right), 6$ percentage of the daily ammonia output norm $\left(\mathrm{F}_{1}\right.$ and $\left.\mathrm{F}_{2}\right)$.

Polygon $\mathrm{A}_{1} \mathrm{~B}_{1} \mathrm{C}_{1} \mathrm{D}_{1} \mathrm{E}_{1} \mathrm{~F}_{1} \mathrm{~A}_{1}$ is an assessment of efficiency of the plant for production of ammonia for the first day, and polygon $\mathrm{A}_{2} \mathrm{~B}_{2} \mathrm{C}_{2} \mathrm{D}_{2} \mathrm{E}_{2} \mathrm{~F}_{2} \mathrm{~A}_{2}$ - for the second day. Circumference that passes through the points $\mathrm{A}, \mathrm{B}$, $\mathrm{C}, \mathrm{D}, \mathrm{E}, \mathrm{F}$ is the standard power, or a mark that meets the specific rate of consumption of specific energy per unit of output. From Fig. 3 it is possible to conclude that effective personnel department worked on the second day than the first. Analyzing and controlling energy efficiency by radiation diagrams possible to assess the state of energy efficiency in the workplace. The smaller the area of polygons (polygons) $\mathrm{A}_{1} \mathrm{~B}_{1} \mathrm{C}_{1} \mathrm{D}_{1} \mathrm{E}_{1} \mathrm{~F}_{1} \mathrm{~A}_{1}$ and $\mathrm{A}_{2} \mathrm{~B}_{2} \mathrm{C}_{2} \mathrm{D}_{2} \mathrm{E}_{2} \mathrm{~F}_{2} \mathrm{~A}_{2}$ better working manufacturing facility.

Likewise it is possible to assess energy efficiency of the process unit, department, company.

3. Comparison of energy production facilities whose consumption depends on many different factors of unequal weight.

In practice must be performed comparing the effectiveness of several technological and energy facilities on the criteria of unequal weight. To carry out this comparison by constructing utility function is not always appropriate. The method requires knowledge of the person who decides mathematical statistics and methods of decision-making. It is therefore necessary to develop or use other methods of finding the best operating production facilities of several of these on several criteria. The simplest method is a priori ranking [3].
At the initial planning stages of the experiment based goals experimenter should select the independent variables (factors), which will later be used in the experiment. Generally, factors selected for analysis prior information that requires the use of different methods to systematize the knowledge gained. To solve the problems of this kind commonly used methods of peer review. These methods are based on receiving and processing data from a survey of experts. Regarding the evaluation and selection of the most significant factors was widespread priori ranking method that can be used to evaluate the energy efficiency of industrial facilities.

Thus, in the ammonia plant by a priori ranking weight ratios are calculated. Power consumption of the plant depends on such factors: heat consumption, recycled water, demineralized water, cost of natural gas output of ammonia. Weight coefficients $K_{w}$ measured by factors present in ammonia plant following: for electric power consumption $K_{w}=0.24$; for heat consumption $K_{w}=0.21$; for consumption of recycled water $K_{w}=0.16$; for demineralized water consumption $K_{w}=0.13$; for the cost of natural gas consumption $K_{w}=0.26$. It is necessary to multiply each value calculated weight ratio in percent (normalized) value criteria specified in Table 1.

Table 2 shows the ratio of energy consumption per unit of output normalized to a value (standard or specific energy consumption norms) subject to weight ratios.

Table 2

The value of the ratio of energy consumption per unit of output normalized taking into account the weight ratio to a value two days in a row

\begin{tabular}{|l|c|c|}
\hline \multicolumn{1}{|c|}{ Parameter } & $\begin{array}{c}\text { The value for the } \\
\text { first day and marking } \\
\text { points on the } \\
\text { radiation diagram, } \%\end{array}$ & $\begin{array}{c}\text { The value for the } \\
\text { second day and } \\
\text { marking points on the } \\
\text { radiation diagram, \% }\end{array}$ \\
\hline $\begin{array}{l}\text { Electrical energy } \\
\text { consumption }\end{array}$ & $100 \cdot 0.24=24\left(\mathrm{~A}_{1}\right)$ & $87 \cdot 0.24=21\left(\mathrm{~A}_{2}\right)$ \\
\hline $\begin{array}{l}\text { Heat energy } \\
\text { consumption }\end{array}$ & $110 \cdot 0.21=23\left(\mathrm{~B}_{1}\right)$ & $90 \cdot 0.21=19\left(\mathrm{~B}_{2}\right)$ \\
\hline $\begin{array}{l}\text { Recycled water } \\
\text { consumption }\end{array}$ & $105 \cdot 0.16=17\left(\mathrm{C}_{1}\right)$ & $91 \cdot 0.16=15\left(\mathrm{C}_{2}\right)$ \\
\hline $\begin{array}{l}\text { Demineralized } \\
\text { water } \\
\text { consumption }\end{array}$ & $108 \cdot 0.13=14\left(\mathrm{D}_{1}\right)$ & $94 \cdot 0.13=12\left(\mathrm{D}_{2}\right)$ \\
\hline $\begin{array}{l}\text { Natural gas } \\
\text { consumption }\end{array}$ & $115 \cdot 0.26=30\left(\mathrm{E}_{1}\right)$ & $95 \cdot 0.26=25\left(\mathrm{E}_{2}\right)$ \\
\hline Ammonia output & $103 \cdot 1.0=103\left(\mathrm{~F}_{1}\right)$ & $96 \cdot 1.0=96\left(\mathrm{~F}_{2}\right)$ \\
\hline
\end{tabular}

Fig. 4 shows the radiation diagram comparing the energy efficiency of ammonia production on the criteria of unequal weight.

The areas of polygons $\mathrm{A}_{1} \mathrm{~B}_{1} \mathrm{C}_{1} \mathrm{D}_{1} \mathrm{E}_{1} \mathrm{~F}_{1} \mathrm{~A}_{1}$ and $\mathrm{A}_{2} \mathrm{~B}_{2} \mathrm{C}_{2} \mathrm{D}_{2} \mathrm{E}_{2} \mathrm{~F}_{2} \mathrm{~A}_{2}$ are calculated. From Fig. 4 it is possible to conclude that for the first day ammonia plant worked worse than for second.

\section{Checking the stability of the technological} process.

Condition of the technological process is characterized by the total error that occurs as a result of accidental and systematic. 


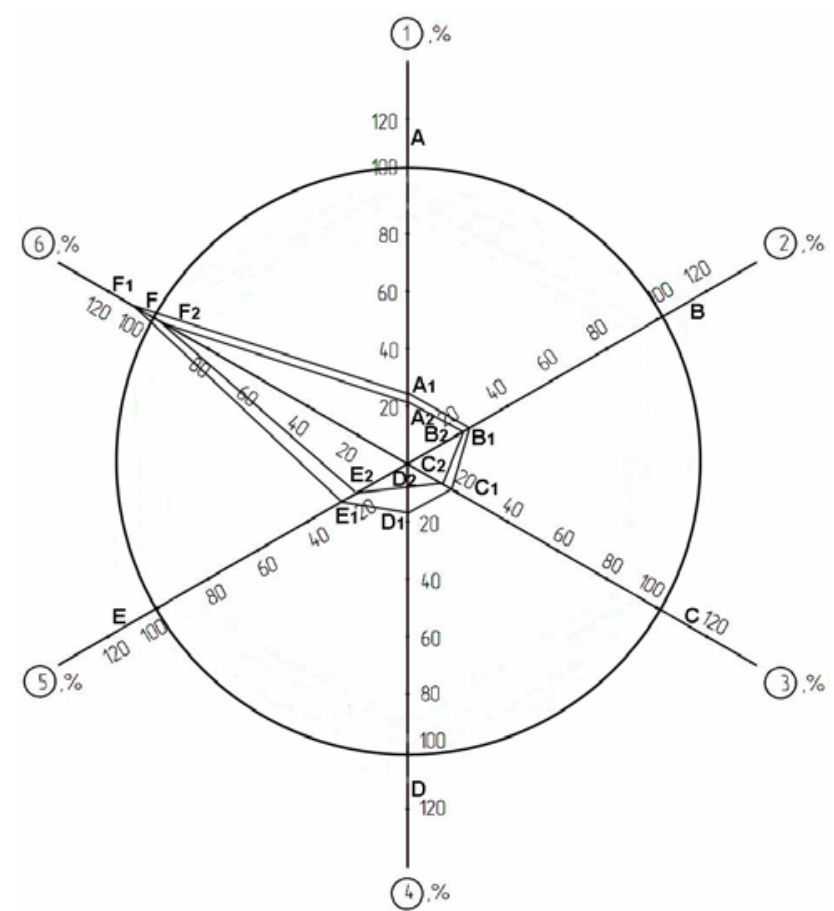

Fig. 4. Radiation diagram comparing the energy efficiency of ammonia production for two days in a row for the nonequilibrium quality criteria

Assessment of the stability process in general is as follows. First a set of experimental data is implemented by measurement parameters controlled sample of units with simultaneous detection of measurement results. Then a table of frequencies; calculated statistical characteristics; determined indicators of process; determined by the status of the level of defects; established distribution law and carried out statistical verification harmonization of the law of the normal law. However, this procedure takes a lot of time, it requires knowledge of mathematical statistics in operating personnel. It is therefore proposed to use to test the stability of the process simpler methods.

In 1957, Charles Holt exponential smoothing developed a method, called two-parameter method Holt [8]. This method takes into account local linear trend present in the time series. If the time series are a tendency to increase, in addition to assessing the current level of assessment it is required and inclination. In the method of Holt value and slope smoothed directly with them using various steel smoothing which to assess the current level and slope, specifying them whenever there are new observations. One advantage of the Holt technique is its flexibility which allows you to select the ratio, which tracks the level and slope.

The basis of the method consists of three Holt equations:

$$
\begin{gathered}
Y_{t}^{p r}=\alpha \cdot\left(Y_{t-1}^{p r}+T_{t-1}\right)+(1-\alpha) \cdot Y_{t}, \\
T_{t}=(1-\beta) \cdot\left(Y_{t}^{p r}-Y_{t-1}^{p r}\right)+\beta \cdot T_{t-1}, \\
Y_{t+p}^{p r}=Y_{t+1}^{p r}+p \cdot T_{t},
\end{gathered}
$$

where $Y_{t}^{p r}$ and $Y_{t-1}^{p r}$ are the projected (smoothed) value of the index in the next and previous times; $Y_{t}$ is the table value of the index in time $t$;
$T_{t-1}$ is the trend value in time $t-1$, determined from (2); $\alpha$ and $\beta$ are the constants of smoothing required to smooth the trend assessment.

Investigations in [8] showed that the value of constant $\alpha$ and $\beta$ determine the stability of the process. The stability of the process is a property that determines the sustainability of its probability distribution parameters for some length of time without interference. The process is considered stable if the controlled parameters do not exceed the limits of control and there is no trend to release them over the limit. The coefficient of variation of power consumption data for the billing period should be minimal. For large chemical plants for the production of ammonia, weak nitric acid, a powerful pumping station supplying water first ascent found that for different processes optimal value smoothing constant $\alpha$ is 0.1 , and the smoothing constant $\beta$ is equal to 0.9 (for stable process).

Knowledge of smoothing constant values allows real-time power consumption compared with the current value calculated by Holt method predicted value. If the values of the smoothing constant $\alpha=0.1$ and $\beta=0.9$ [8] actual value of power consumption coincides with the predictable, the technological process with the stable.

Reducing or increasing the last time the sample values of power consumption makes it impossible to make a proper conclusion about the proper conduct of the process. To test the stability of the process proposed to use the autocorrelation coefficient (AC) [9] of the first, second and further orders to check the stability and efficiency of process of energy consumption.

A number of studies on the efficiency of AC utilization for the evaluation process at several sites of the chemical industry are carried out. Data on hourly power consumption $P$ of the large ammonia plant chemical enterprise for several days of the year 2016 are collected. Sample data consumption is shown in Table 3.

Table 3

The values of hourly electricity consumption of the large ammonia plant for one of the days in 2016

\begin{tabular}{|l|c|c|c|c|c|c|c|c|}
\hline $\begin{array}{l}\text { Interval } \\
\text { No. }\end{array}$ & 1 & 2 & 3 & 4 & 5 & 6 & 7 & 8 \\
\hline $\begin{array}{l}P, \\
\text { MW·year }\end{array}$ & 37.264 & 37.275 & 37.290 & 37.189 & 37.058 & 37.088 & 37.131 & 37.124 \\
\hline $\begin{array}{l}\text { Interval } \\
\text { No. }\end{array}$ & 9 & 10 & 11 & 12 & 13 & 14 & 15 & 16 \\
\hline $\begin{array}{l}P, \\
\text { MW·year }\end{array}$ & 37.112 & 37.074 & 37.171 & 37.201 & 37.239 & 37.259 & 37.189 & 37.162 \\
\hline $\begin{array}{l}\text { Interval } \\
\text { No. }\end{array}$ & 17 & 18 & 19 & 20 & 21 & 22 & 23 & 24 \\
\hline $\begin{array}{l}P, \\
\text { MW·year }\end{array}$ & 37.450 & 37.465 & 37.527 & 37.510 & 37.472 & 37.267 & 37.074 & 37.133 \\
\hline
\end{tabular}

*The coefficient of variation of the sample $0.24 \%$.

The last (the 24-th) the sample ranges from 0 to $100 \%$ in increments of $25 \%$ in the range from 0 to $75 \%$ and $5 \%$ in the range of $75 \%$ to $100 \%\left(P_{24}^{\prime}=K \cdot P_{24}\right)$, where $K$ is the ratio changed recently the sample to its full value. Coefficient $K=0-1.0$; it takes the values $0 ; 0.25$; $0.5 ; 0.75 ; 0.8 ; 0.85 ; 0.9 ; 0.95 ; 1.0$. Estimated spacecraft first, second, third order for each of the samples when changing the last sample. 
Investigations have shown that there are three types depending on the size AC last modified the sample (Fig. 5).

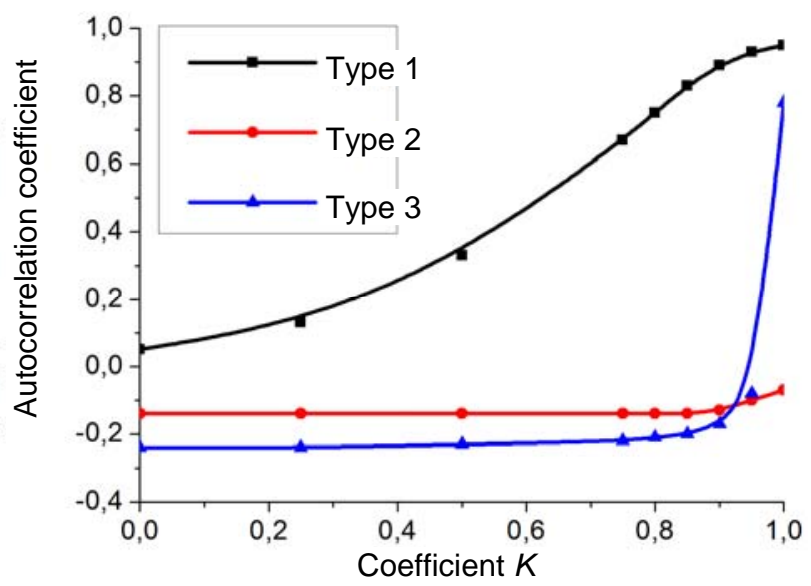

Fig. 5. Dependence of AC of the first order on changing the sample last

For the first and third type depending spacecraft first order proportional to the changing value of the last sample. Therefore, when there is such a relationship, the $\mathrm{AC}$ should be used to control power consumption mode. The calculation results proved that the AC swings of the first order for the first and third type depends 30-40\% more than the second or third order. Therefore, it is better to use to control power consumption mode.

For the first type is characterized by a strong sensitivity to the dramatic change in the value of the last sample and the zero power consumption. Thus, by changing the last value of the sample $25 \%$ spacecraft first order reduced 2.5 times. AC describes the closeness linear relation only current and previous number of levels. Therefore, the autocorrelation coefficient can judge the presence of linear (or close to linear) trend [9].

For the third type of spacecraft observed a strong dependence of the first order from changes in the value of the last sample. AC of the second and third order for the third type of $\mathrm{AC}$ is resembling the first order for this type.

For some time series with strong non-linear trend (for example, take the form of a parabola of the second order, or exponential) autocorrelation coefficient series output levels may be close to zero. When sampling spacecraft dependence on changes in the value of the sample resembles the last second type (Fig. 5), then the $\mathrm{AC}$ is not suitable for the control of energy consumption.

To calculate AC of the second and third orders for all types depending on its value last modified the sample is also necessary in order to use the Ljung-Box for the autocorrelation [9].

All the above economic and mathematical methods may assist operational staff to quickly assess the situation at work, better monitor energy production facilities and in a short time to take measures to ensure the stability of the process, which corresponds to the concept of Smart Grid [10].

\section{Conclusions.}

1. We proved the feasibility of a number of economic and mathematical methods for monitoring the energy efficiency of production facilities and testing technological process stability.

2. The easiest way to control of the energy efficiency of technological processes when the electric load depends on two parameters, it is a way to use triangular coordinates which are useful for visualization and monitoring of the technological process.

3 . The method of a priori ranking and morphological method are used for comparison of several similar energy production of the chemical industry, where energy consumption depends on many factors. These methods are recommended for use for the evaluation of energy efficiency in other industrial facilities.

4. An indication of the stability of the process is the identity of the current value of the power consumption calculated by the Holt method predicted value at predefined optimal smoothing constant.

5. For the first time autocorrelation coefficient is applied to evaluate the stability of technological processes. It is proved that at changing the range in a small power consumption value of the sample with a probability of $66 \%$ is a significant change autocorrelation coefficient of the first or second order.

6. Considered in the paper economic and mathematical methods can be used to support the actions and decisions of operating personnel to conduct monitoring energy efficiency and stability of production facilities, to visualize current information, to support actions and feasibility of making human-operator's decisions that will promote Smart Grid concept in the industry.

\section{REFERENCES}

1. Denysenko M. A. Spetsial'ni pytannya elektropostachannya: navch. posib. Ch.I.: Vybir elementiv elektropostachal'nykh system na osnovi stokhastychnoho modelyuvannya protsesiv, shcho vidbuvayut'sya $v$ nykh [Special issues of power supply. Part 1. Selecting items of electricity supply systems based on stochastic modeling of processes occurring in them]. Kyiv, NTUU «KPI» Publ., 2009. 288 p. (Ukr).

2. Zamulko A.I., Bederak Ya.S. Comprehensive statistical data analysis of active power consumption, energy expenditures and production volumes. Power Engineering: Economics, Technique, Ecology, 2014, no.2, pp. 79-83. (Ukr).

3. Gorbunov V.M. Teoriia priniatiia reshenii [Decision making theory]. Tomsk, NRTPU Publ., 2010. 67 p. (Rus).

4. Uiler D., Chambers D. Statisticheskoe upravlenie protsessami. Optimizatsiia biznesa s ispol'zovaniem kontrol'nykh kart Shukharta [Statistical control of process. Optimization of business using Shewhart control charts]. Moscow, Alpina Business Books Publ., 2008. 419 p. (Rus).

5. Bederak Ya.S. Visualization of reports and templates, which are formed in the monitoring systems of power consumption and energy management. Bulletin of Kharkiv Petro Vasylenko National Technical University of Agriculture, 2012, no.130, pp. 3-5. (Ukr).

6. Voloshko A.V., Bederak Ya.S., Lutchyn T.M. The problems of selection of optimal mathematical model of energy consumption at industrial enterprises. Eastern-European Journal of Enterprise Technologies, 2013, no.5/8(65), pp. 19-23. (Ukr). doi: 10.15587/1729-4061.2013.18122.

7. Nakhodov V.F., Borychenko O.V. Monitoring and analysis of implementation of established «standards» in the statistical 
control systems of effective use of electric energy. Informational collected papers «Promyslova electroenergetyka ta elektrotekhnyka» Promelektro, 2011, no.2, pp. 16-23. (Ukr).

8. Stetsenko Y.V., Bederak Ya.S. Recovery and operational forecasting by Holt's method of electricity consumption at enterprises with a continuous work cycle. Electronic modeling, 2015, no.4, pp. 119-126. (Rus).

9. Luk'yanenko I.G., Krasnikova L.I. Ekonometryka [Econometrics]. Kyiv, Tovaristvo «Znannya» KOO Publ., 1998. 494 p. (Ukr).

10. Kobets B.B., Volkova I.O. Innovatsionnoe razvitie elektroenergetiki na baze kontseptsii Smart Grid [Innovative development of the electric power on the basis of Smart Grid concept]. Moscow, IAC Energiya Publ., 2010, 208 p. (Rus).

Received 11.10.2016

Ya.S. Bederak, Engineer, PJSC «AZOT»,

72, Pervomayskaya Str., Cherkassy, 18014, Ukraine, phone +380472392979 ,

e-mail: ei@uch.net

How to cite this article:

Khlopenko N.J., Khlopenko I.N. Structural synthesis of a stabilizing robust controller of the rotor flux linkage. Electrical engineering \& electromechanics, 2017, no.1, pp. 67-72. doi: 10.20998/2074-272X.2017.1.11. 